\title{
STUDY OF INSULIN RESISTANCE IN PATIENTS WITH CANCER
}

Tamara Vatseba

Department of Endocrinology, Ivano-Frankivsk National Medical University, Ivano-Frankivsk, Ukraine.

E-mail: tamara.vatseba@gmail.com

\section{ДОСЛІДЖЕННЯ ІНСУЛІНОРЕЗИСТЕНТНОСТІ У ПАЦІЕНТІВ 3 ОНКОЛОГІЧНИМИ ЗАХВОРЮВАННЯМИ}

\author{
Т.С. Вацеба
}

Івано-Франківський національний медичний університет, Україна

\begin{abstract}
The pro-oncogenic effects of obesity, insulin resistance and hyperinsulinemia have been proven in some types of cancer, as well as in type 2 diabetes mellitus.

The objective of the research was to investigate the state of insulin resistance in patients suffering from oncological diseases and to compare insulin correlations in patients with type 2 diabetes mellitus and those with cancer.

Materials and Methods. The study included the following groups of patients: Group I included healthy individuals (the control group); Group II comprised patients with type 2 diabetes mellitus; Group III included patients with cancer: subgroup IIIa comprised patients with breast cancer, subgroup IIIb included patients with endometrial cancer, subgroup IIIc comprised patients with colorectal cancer. Fasting blood glucose was determined by glucose oxidase method; hemoglobin A1c was determined by ion exchange chromatography; the levels of insulin and insulin-like growth factor-1 were determined by immune-enzyme method. Insulin resistance was assessed by the homeostatic model assessment for insulin resistance index. The results obtained were analyzed using statistical analysis.

Results. Obesity was confirmed in all the groups of patients with cancer. Significantly higher body mass index, as compared to the control group, was found in patients with endometrial cancer $(\mathrm{p}=0.008)$. In comparison with the control group, the levels of insulin and insulin-like growth factor-1 increased significantly in all groups of patients with cancer $(\mathrm{p}<0.001)$. Fasting blood sugar levels and hemoglobin Alc did not differ from the indicators in the control group $(\mathrm{p}>0.05)$. Direct correlations between insulin and body mass index $(\mathrm{p}<0.05)$, insulin-like growth factor-1 $(\mathrm{p}<0.05)$ and the homeostatic model assessment for insulin resistance index in patients of Group II and Group III were detected $(\mathrm{p}<0.05)$.

Conclusions. In obese patients with breast, uterine and colorectal cancer, there was found a decrease in insulin sensitivity, which might increase the proliferative effects of insulin and insulin-like growth factor-1. Correlation analysis showed a probable association of cancer and diabetes mellitus due to obesity and insulin resistance.
\end{abstract}

Keywords: Obesity; Insulin Resistance; Oncological Diseases; Type 2 Diabetes Mellitus.

Резюме. Проонкогенний вплив ожиріння, інсулінорезистентності та гіперінсулінемії доведений при деяких видах раку, а також при цукровому діабеті (ЦД) 2 типу. Мета роботи: дослідити стан інсулінорезистентності у хворих з онкологічними захворюваннями та порівняти кореляційні зв'язки інсуліну у хворих на ЦД 2 типу та в хворих на рак.

Матеріали і методи. В дослідження включені наступні групи пацієнтів: I - здорові (контрольна група); II - хворі на ЦД 2 типу; III - хворі з онкологічними захворюваннями: IIIa - молочної залози, IIIb - ендометрію, IIIc - 3 колоректальним раком. Глікемію натще визначали глюкозооксидазним методом, НbAlc - методом іонообмінної хроматографії; рівні інсуліну та інсуліноподібного фактора росту-1 (IGF-1) - імуноферментним методом. Інсулінорезистентність оцінювали за індексом НОМА-IR. Проведений статистичний аналіз отриманих результатів.

Результати. У всіх групах пацієнтів з онкологічними захворюваннями було підтверджене ожиріння. Достовірно вищий IMT, у порівнянні з групою контролю, виявлений у пацієнтів з раком тіла матки $(\mathrm{P}=0,008)$. У пацієнтів з онкологічними захворюваннями, незалежно від локалізації, виявлене підвищення рівнів інсуліну та IGF-1 у порівнянні з контрольною групою $(\mathrm{P}<0,001)$. Показники глікемії натще та HbA1c не відрізнялись від показників контрольної групи (P > 0,05). В хворих на ЦД 2 типу II групи і в пацієнтів 3 онкологічними захворюваннями III групи виявлені прямі кореляційні зв язки інсуліну з IMT $(\mathrm{P}<0,05)$, IGF-1 $(\mathrm{P}<0,05)$ та 3 індексом HOMA-IR $($ P $<0,05)$.

Висновки. 1. У хворих з онкологічними захворюваннями молочної залози, тіла матки та колоректальної локалізації з ожирінням виявлене зниження чугливості до інсуліну, що може посилювати проліферативні ефекти інсуліну та IGF-1. 2. Кореляційний аналіз показує ймовірну асоціацію раку та ЦД через вплив ожиріння та інсулінорезистентність.

Ключові слова: ожсріння, інсулінорезистентність, онкологічні захворювання, цукровий діабет 2 типу.

Problem Statement and Analysis of the Recent Research

The latest studies and numerous clinical observations have proven an increased risk of cancer of various localizations in patients with type 2 diabetes mellitus (DM) [22, 12, 24]. The impairment of the immunological control and recovery, chronic immunological depression in type 2 DM lead to loss of the body's ability to regulate the processes of cell division, apoptosis, and survival in a proper way [28].

In addition to the impaired immunological regulation, the mechanisms of association of type $2 \mathrm{DM}$ and cancer are recognized as the effects of obesity, hyperinsulinemia, cytokine imbalance, hyperglycemia, and oxidative stress [6]. The procarcinogen effect of obesity is due to a combination of dysmetabolic and dyshormonal disorders [2]

Hyperinsulinemia, caused by insulin resistance, both endogenous (prediabetes, metabolic syndrome, obesity, type 2 DM, polycystic ovary syndrome) and exogenous (insulin therapy for type 1 and 2 DM), increases the risk of cancer [5].

The presence of insulin resistance has been proven not only in type $2 \mathrm{DM}$ [4]. The important effects of obesity, insulin resistance and hyperinsulinemia have been shown in some cancers [10].

Insulin is a hormone with pronounced anabolic effects; it has a hypoglycemic effect through the activation of insulin 
receptors-B (IR-B); mitogenic and antiapoptotic effects are realized through the activation of IR-A. Insulin causes malignant transformation of cells through the impairment of the mitotic processes and inhibition of apoptosis, due to the rapid transition of cells from the G1 period to the S-period of the cell cycle interphase [16].

In addition, hyperinsulinemia promotes carcinogenesis through the effects of insulin-like growth factor-1 (IGF-1), which is physiologically like insulin, has anabolic effects, activates protein synthesis, and inhibits apoptosis [8].

Insulin, IGF-1 and nutrient content are known to be epigenetic factors influencing oncogenesis because they are regulators of intracellular signaling pathways, in particular PI3K/ AkT/mTOR, which controls cellular metabolism, apoptosis and survival. The role of PI3K/AkT/mTOR in oncological diseases (OD) and type $2 \mathrm{DM}$ (as a system of realization of oncogenic influences of pathogenetic factors of diabetes) has been proven $[18,17,19]$. Hyperglycemia is an important factor of oncogenesis in patients with DM. It induces genetic mutations due to oxidative stress, accumulation of reactive oxygen species (ROS) and activation of the ROS/MAPK/mTOR signaling pathway $[6,32]$.

Taking into account the fact that obesity is a factor of oncogenesis in many forms of cancer and considering the importance of insulin and IGF-1 in the activation of PI3K/Akt/ mTOR in type $2 \mathrm{DM}$ and cancer, scientific interest leads to the study of metabolic disorders in patients with OD.

The objective of the research was to investigate insulin resistance in patients with cancer and to compare insulin correlations in cancer and type $2 \mathrm{DM}$.

\section{Materials and Methods}

The study was conducted in accordance with the guidelines of the 1975 Declaration of Helsinki and its second (1983) revision. There were examined 72 patients. Patients were divided into the following groups: Group I included healthy individuals (the control group) $(\mathrm{n}=16)$; Group II comprised patients with type 2 DM $(\mathrm{n}=28)$; Group III included patients with OD: subgroup IIIa comprised patients with breast cancer $(n=10)$, subgroup IIIb included patients with endometrial OD $(\mathrm{n}=10)$, subgroup IIIc comprised patients with colorectal cancer $(\mathrm{n}=8)$.

Determination of fasting blood glucose was performed by glucose oxidase method; haemoglobin Alc (HbAlc) was determined by ion exchange chromatography. Insulin and IGF-1 levels were determined by immune-enzyme method on a stat fax $303+$ automatic analyzer (USA) in interdepartmental scientific laboratory of the Ivano-Frankivsk National Medical University using Insulin ELISA, EIA-2935 and IGF-1 600 ELISA, EIA-4140(DRG, Germany) diagnostic kits. According to the kits used, the normal insulin level was considered 2-25 mIU/L, the IGF-1 level - 150-350 ng/ml.

To determine the presence and degree of obesity, body mass index (BMI) was calculated by the formula: $\mathrm{BMI}=($ body weight $(\mathrm{kg}) /\left(\right.$ height $\left.\left(\mathrm{m}^{2}\right)\right)$. Insulin resistance was determined by the homeostatic model assessment for insulin resistance (HOMA-IR) index by the formula: HOMA-IR = fasting glucose $\mathrm{x}$ insulin / 22.5. Insulin resistance was established at HOMAIR $>3.0$.

Statistical analysis of the data was performed using Statistica 12.0 (StatSoft Inc., USA). The differences between the indicators of the control and experimental groups were determined by Student's t-test. Differences were considered significant at $\mathrm{p}<0.05$. The correlation was assessed by the Pearson coefficient (rxy).

\section{Results}

The clinical characteristics of patients were studied: BMI and age, as well as laboratory parameters reflecting carbohydrate metabolism and insulin sensitivity in different comparison groups (Table 1).

According to the obtained data, normoglycemia was detected in the control group, mean BMI met the criteria for overweight, the HOMA-IR index $<3.0$ indicated the absence of insulin resistance (Table 1).

BMI of patients with type 2 DM was $31.82 \pm 5.53 \mathrm{~kg} / \mathrm{m}^{2}$, which confirmed the obesity in patients of this group. The average levels of blood insulin and IGF-1 levels did not exceed the respective reference values according to the reagents used. Fasting blood glucose and HbAlc levels showed no compensation of DM (fasting blood glucose $>6.0 \mathrm{mmol} / \mathrm{l}$, HbA1c level > 7.0\%). The HOMA-IR index of $7.62 \pm 3.21$ confirmed insulin resistance in patients of this group (Table 1).

Comparative analysis using Student's t-test confirmed significantly higher levels of insulin, IGF-1, fasting glucose, HbAlc and HOMA-IR index in the patients of Group II as compared to the control group $(\mathrm{p}<0.05)$. Patients did not differ significantly in age and BMI ( $>0.05)$, although mean BMI of patients in Group II met the criteria for stage I obesity, and in the control group - the criteria for overweight.

According to the results obtained, OD in the patients of Group III were diagnosed in those who were older than 55 years. Obesity was confirmed in all groups of patients with cancer. Significantly higher BMI, as compared to the control group, was found in patients with uterine cancer who belonged to Group IIIb $(\mathrm{t}=2.86 ; \mathrm{p}=0.008)$. Elevated blood insulin levels

Table 1. Indicators of hydrocarbon metabolism and insulin sensitivity in patients with cancer and type $2 \mathrm{DM}(n=72)(M \pm S D)$

\begin{tabular}{|c|c|c|c|c|c|c|c|}
\hline Groups & $\begin{array}{l}\text { Age, } \\
\text { years }\end{array}$ & $\begin{array}{l}\mathrm{BMI}, \\
\mathrm{\kappa g} / \mathrm{m}^{2}\end{array}$ & $\begin{array}{l}\text { Insulin, } \\
\mathrm{mIU} / \mathrm{L}\end{array}$ & $\begin{array}{l}\text { IGF-1, } \\
\mathrm{ng} / \mathrm{ml}\end{array}$ & $\begin{array}{l}\text { Fasting } \\
\text { glucose, } \\
\mathrm{mmol} / 1\end{array}$ & $\begin{array}{c}\mathrm{HbA} 1 \mathrm{c}, \\
\%\end{array}$ & $\begin{array}{l}\text { HOMA- } \\
\text { IR }\end{array}$ \\
\hline & & 2.79 & & & & & \\
\hline & $\begin{array}{c}56.07 \pm \\
6.87\end{array}$ & $\begin{array}{c}31.82 \pm \\
5.53\end{array}$ & & & $\begin{array}{l}7.57 \pm \\
2.06^{*}\end{array}$ & & $\begin{array}{l}7.62 \pm \\
3.21 *\end{array}$ \\
\hline $\begin{array}{l}\text { Group IIIa } \\
(\mathrm{n}=10)\end{array}$ & $\begin{array}{c}59.70 \pm \\
11.28\end{array}$ & $\begin{array}{c}31.38 \pm \\
1.93\end{array}$ & $\begin{array}{c}11.13 \pm \\
2.09 * / \#\end{array}$ & $\begin{array}{c}276.29 \pm \\
30.49 * / \#\end{array}$ & $\begin{array}{l}4.61 \pm \\
0.77 \#\end{array}$ & $\begin{array}{l}5.71 \pm \\
0.36 \#\end{array}$ & $\begin{array}{c}2.26 \pm \\
0.56 * / \#\end{array}$ \\
\hline $\begin{array}{l}\text { Group IIIb } \\
(n=10)\end{array}$ & $\begin{array}{c}63.50 \pm \\
3.98\end{array}$ & $\begin{array}{c}33.30 \pm \\
3.54^{*}\end{array}$ & $\begin{array}{c}13.35 \pm \\
1.96 * / \#\end{array}$ & $\begin{array}{c}479.34 \pm \\
286.97 * / \#\end{array}$ & $\begin{array}{l}4.65 \pm \\
0.84 \#\end{array}$ & $\begin{array}{l}5.65 \pm \\
0.45 \#\end{array}$ & $\begin{array}{c}2.80 \pm \\
0.82 * / \#\end{array}$ \\
\hline $\begin{array}{l}\text { Group IIIc } \\
(\mathrm{n}=8)\end{array}$ & $\begin{array}{l}66.30 \pm \\
11.56\end{array}$ & $\begin{array}{c}31.19 \pm \\
4.36\end{array}$ & $\begin{array}{c}14.47 \pm \\
4.13 * / \#\end{array}$ & $\begin{array}{l}215.25 \pm \\
56.69 *\end{array}$ & $\begin{array}{l}4.50 \pm \\
0.87 \#\end{array}$ & $\begin{array}{l}528 \pm \\
0.52 \#\end{array}$ & $\begin{array}{c}2.88 \pm \\
0.89 * / \#\end{array}$ \\
\hline
\end{tabular}

Notes: $1 . *$ - significant difference in comparison with the indicators of the control group $(\mathrm{p}<0.05) ; 2$. \#- significant difference in comparison with the indicators of the patients of Group II $(p<0.05) ; 3$. The difference was determined by the t-Student's t test 


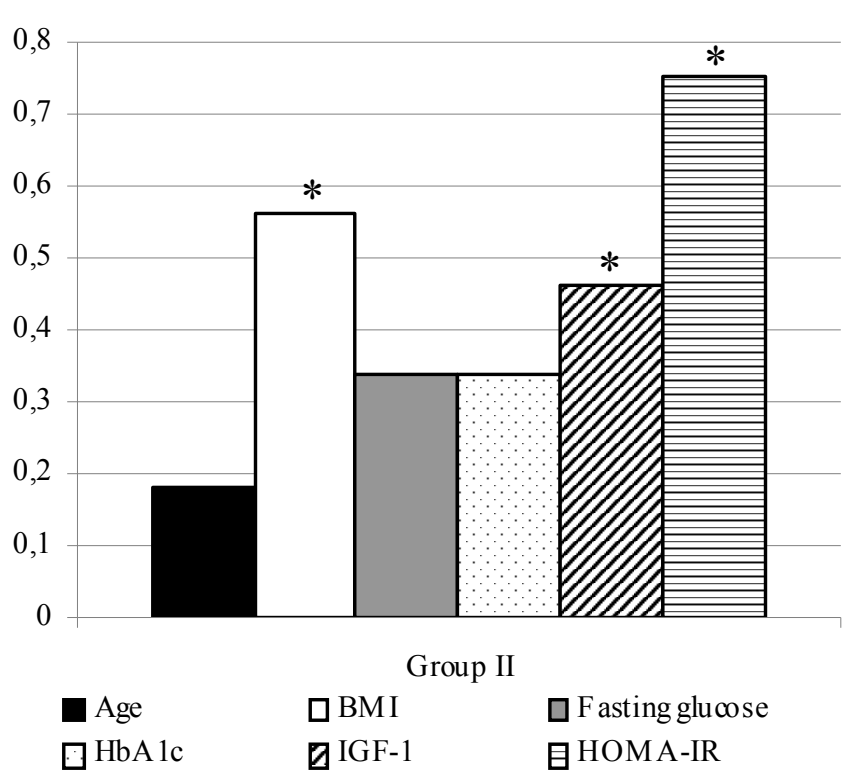

Fig. 1. Correlation of insulin in patients of Group II; * - statistically significant relationship $(\mathbf{p}<0.05)$

were found in all groups of patients with OD as compared to the control group: in patients with breast cancer - $(\mathrm{t}=3.86$; $\mathrm{p}=0.001)$, uterine cancer $-(\mathrm{t}=6.55 ; \mathrm{p}<0.001)$ and colorectal cancer $-(\mathrm{t}=5.41 ; \mathrm{p}<0.001)$, respectively.

IGF-1 level in patients with OD was higher than that in the control group as well: in patients with breast cancer $(t=12.70$; $\mathrm{p}<0.001)$, uterine cancer $(\mathrm{t}=4.74 ; \mathrm{p}<0.001)$ and colorectal cancer $(\mathrm{t}=4.65 ; \mathrm{p}<0.001)$, respectively. In women of Group $\mathrm{IIIb}$, the level of IGF-1 was the highest $(479.34 \pm 286.97 \mathrm{ng} / \mathrm{ml})$ and exceeded the reference values $(\mathrm{N}=150-350 \mathrm{ng} / \mathrm{ml})$. Moreover, patients of Group IIIa had higher level of IGF-1 as compared to patients with type $2 \mathrm{DM}(\mathrm{t}=4.03 ; \mathrm{p}<0.001)$, as well as the patients of Group IIIb $(t=5.11 ; \mathrm{p}<0.001)$.

Fasting glycemia in patients with OD corresponded to normal values of prandial glycemia; $\mathrm{HbAlc}$ level confirmed

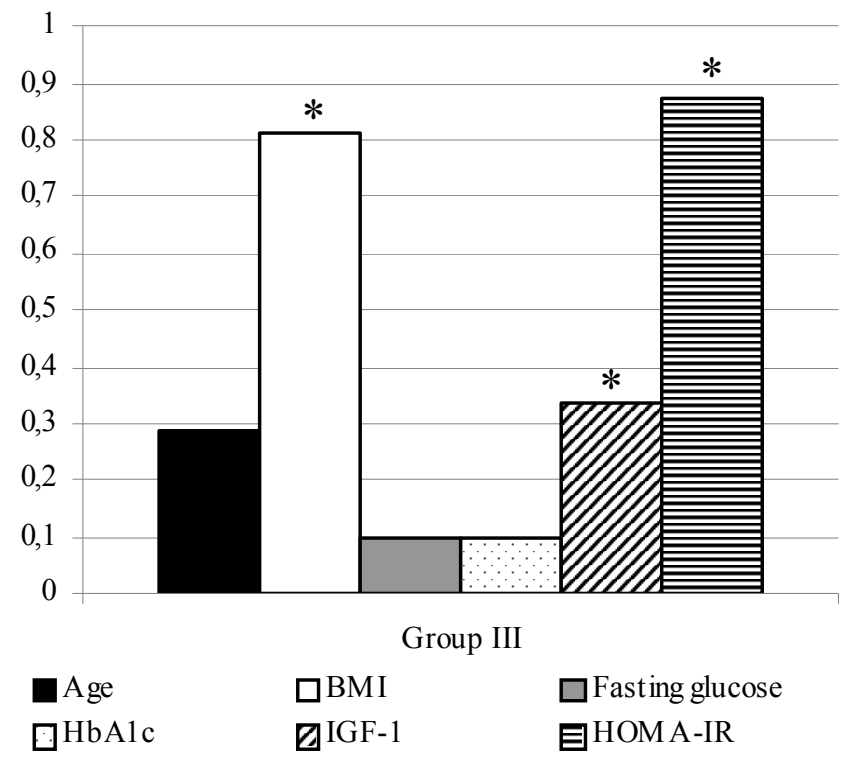

Fig. 2. Correlation of insulin in patients of Group III; * - statistically significant relationship $(p<0.05)$ normoglycemia in patients of both Group III and the control group, without a significant difference between them $(\mathrm{p}>0.05)$. The HOMA-IR index, as compared to the control group, was higher in patients of Group IIIa $(\mathrm{t}=3.24 ; \mathrm{p}=0.003)$, Group IIIb $(\mathrm{t}=4.61 ; \mathrm{p}<0.001)$ and Group IIIc $(\mathrm{t}=4.66 ; \mathrm{p}<0.001)$. The HOMA-IR index in patients of Group III did not confirm insulin resistance (Table 1).

Correlation analysis of interrelations between insulin and clinical characteristics of patients with type $2 \mathrm{DM}$, as well as the indicators reflecting carbohydrate metabolism and sensitivity to insulin was conducted. In patients of Group II, a direct correlation between insulin and BMI $(r=0.560 p<0.05)$, IGF-1 $(\mathrm{r}=0.462, \mathrm{p}<0.05)$ and the HOMA-IR index $(\mathrm{r}=0.754$, $\mathrm{p}<0.05$ ) was found (Fig. 1 ).

The analysis of correlation relationships in Group III revealed a direct correlation between insulin and BMI $(\mathrm{r}=0.812 ; \mathrm{p}<0.05)$, IGF-1 $(\mathrm{r}=0.334 ; \mathrm{p}<0.05)$ and the HOMAIR index ( $r=0.872 ; p<0.05)$ (Fig. 2), similarly to patients of Group II (Fig. 1).

\section{Discussion}

According to the data obtained, obesity was detected in all the patients of Group III (breast, uterine and colorectal cancer). Numerous studies have proven the negative impact of obesity in the potentiation of oncogenic processes, especially the reproductive system organs, including the patients with type 2 $\mathrm{DM}[31]$.

Obesity is known to promote the conversion of androgen precursors to estrogens and their interaction with receptors of hormone-dependent target organs [14, 27]. Adirect dependence of the level of free sex hormones on BMI in postmenopausal women has been proven. Estradiol was found to accelerate the proliferation of endometrial cells and inhibit apoptosis, as well as to stimulate the local synthesis of IGF-1 in endometrial tissue. Insulin and IGF-1 are proven to be able to stimulate endometrial proliferation directly, showing synergistic effects with estrogen [29]. Obesity was found in $31.2 \%$ of women with breast cancer. The direct dependence of the incidence of breast cancer on the degree of obesity has been proven [1]. The negative impact of obesity in colorectal cancer has been proven as well [11].

The HOMA-IR index in patients of Group III was lower than 3.0, which excluded the presence of insulin resistance. However, patients of this group had the HOMA-IR index $>2.5$, that was higher than in the control group $(p<0.05)$. In all localizations of OD, IGF-1 was higher than in the control group $(\mathrm{p}<0.05)$.

The analysis of correlation relationships of insulin in patients of Group II and Group III proved a direct correlation between insulin and BMI, IGF-1, and the HOMA-IR index. These correlations provided additional evidence for the effect of obesity on insulin sensitivity and its concentration in the blood.

Obesity, which is recognized as a condition of chronic nonspecific inflammation, causes the activation of oncogenesis via dyshormonal, as well as cytokine imbalance, which explains its effects in colorectal cancer.

Direct correlations between BMI, insulin and the HOMAIR index in cancer patients can be explained by the effects of pro-inflammatory cytokines, the levels of which increase significantly in obesity. Among the major cytokines involved 
in the regulation of insulin sensitivity and oncogenesis, there are tumor necrosis factor alpha (TNF- $\alpha$ ), interleukine-6(IL-6), adiponectin (APN) and leptin.

TNF- $\alpha$ affects the state of insulin sensitivity by reducing the translocation of glucose transporter type 4 (GLUT-4) to the membrane and inhibiting the activity of insulin receptor substrate 1 (IRS-1) [23]. According to the studies, TNF- $\alpha$ exhibits pro-oncogenic properties in chronic inflammation, especially obesity [9].

The synthesis of IL-6, involved in the regulation of cell sensitivity to insulin and carcinogenesis, significantly increases in obesity as well [16]. IL-6 has been shown to be positively correlated with insulin levels, regardless of the presence of insulin resistance. The effect of IL-6 on insulin synthesis is associated with the activation of adenosine monophosphatekinase, which stimulates $\beta$-cells of the pancreas [7]. Prolonged exposure to IL-6 in adipocytes inhibits the activity of IRS-1 and GLUT-4, similar to TNF- $\alpha$. In addition, in fat cells, IL-6 inhibits the transcriptional activity of the IRS-1, GLUT-4 genes and adiponectin and activates the expression of proinflammatory cytokines [18].

The direct dependence of leptinemia on patients' BMI has been proven. Leptin stimulates the local synthesis of estrogens by aromatization of androgens directly in the adipose tissue of the mammary gland (similar to IL-6), and activates the ER $\alpha$ gene, contributing to the proliferative effects of estrogens. The role of hyperleptinemia in the development of colorectal cancer has been proven [21].

Hyperproduction of proinflammatory cytokines enhances lipolysis by reducing perlipin and fat-specific protein 27 (FSP27). Free fatty acids adversely affect APN synthesis in adipose tissue, maintaining the state of insulin resistance and susceptibility to OD [26].

These correlations were inherent in patients with both OD and type $2 \mathrm{DM}$, which additionally confirmed the significant role of pathogenetic factors of type $2 \mathrm{DM}$ in the activation of oncogenesis [30].

A positive correlation between insulin and IGF-1 indicated the effect of hyperinsulinemia on the level and activity of IGF-1.

IGF-1 concentration is known to be regulated through the influence of somatotropic hormone (STH), which has counterinsular effects. However, the concentration of this growth factor depends on insulin concentration in the blood and the nutrient balance. Nutritional deficiency, hypoinsulinemia (e.g., in type 1 DM) lead to a decrease in IGF-1 [25].

In contrast, in hyperinsulinemia, insulin resistance and hyperglycemia (type 2 DM), the level of IGF-1 increases, due to a decrease in the level of globulin, that binds IGF-1 due to hyperinsulinemia. In addition, compensatory hyperinsulinemia in insulin resistance increases the synthesis of IGF-1 in the liver. In obesity, the resistance to IGF-1 at the level of muscular tissue receptors has been proven [13, 3], i.e., insulin resistance contributes to elevated levels of IGF-1.

Thus, the results of the study showed significantly higher levels of insulin and the HOMA-IR index in obese patients with breast, uterine and colorectal cancer as compared to the control group. Similar correlations of insulin in patients with type $2 \mathrm{DM}$ and those with cancer of the mentioned localizations were detected.

\section{Conclusions}

1. In obese patients with breast, uterine and colorectal cancer, a decrease in insulin sensitivity was found, which might increase the proliferative effects of insulin and IGF-1.

2. Correlation analysis showed a probable association of cancer and DM due to obesity and insulin resistance.

\section{Gratitude}

The author expresses gratitude to the administration and employees of the Ivano-Frankivsk Regional Clinical Hospital and the Precarpathian Clinical Oncology Center for assistance in selecting patients for research; to the head and staff of the Interdepartmental Scientific Laboratory of the Ivano-Frankivsk National Medical University for assistance in conducting laboratory tests.

\section{Ethics Policy}

The study is a fragment of the research project "Epidemiology of Oncological Diseases in Patients with Diabetes Mellitus and the Effect of Antihyperglycemic Drugs on Oncogenesis Markers" (registration number 0117U005263), included into the complex research work of the Ivano-Frankivsk National Medical University "Pathogenetic Mechanisms of Development of Changes in Organs of the Respiratory, Endocrine, Nervous Systems in the Modeled Pathological Conditions and Their Correction" (registration number 0117U001758), without special funding.

The study protocol was reviewed and approved by the Ethics Committee of the Ivano-Frankivsk National Medical University (protocol No 97/17 of October 19, 2017).

No experiments and tests on humans and animals were conducted.

There was no financial support for the study.

\section{Conflicts of Interest}

The author declares that there is no conflict of interest

\section{References}

1. Ashrafyan LA, Ovchinnikova OA, Antonova IB et al. The role of the metabolic syndrome in the pathogenesis of breast cancer and the possibility of its correction. RSCRR of Ministry of Health and Social Development of Russian Federation. 2007;12. [published in Russian]

2. Vatseba TS, Sokolova LK, Pushkarev VM. The effect of obesity on the formation of cancer risk in patients with type 2 diabetes mellitus (literature review). International Journal of Endocrinology. 2020;16(2):161-167. Available from: https://doi.org/10.22141/22240721.16.2.2020.201303

3. Gennadinik AG, A Nelaeva AA. Rol insulinopodobnogo faktora rosta-I v metabolizme, regulyatsii kletochnogo obnovleniya $\mathrm{i}$ protsessakh stareniya. Obesity and Metabolism. 2010;2:10-15. Available from: https://doi.org/10.14341/2071-8713-5203

4. Leshchenko ZhA. Patohenetychna rol nadlyshku tsyrkuliuiuchykh neeteryfikofanykh zhyrnykh kyslot $u$ formufanni insulinorezystentnosti. Problems of Endocrine Pathology. 2009;1:82-90.

5. Misnikova IV. Diabetes and cancer. RMJ.2016;20:1346-1350. [published in Russian]

6. Pushkarev VM, Sokolova LK, Pushkarev VV et al. Biochemical mechanisms connecting diabetes and cancer. Effects of methormine. Endocrinology. 2018;23(2):167-179.

7. Schwarz V. Dvoystvennaya rol interleykina-6 v razvitiyi insulinoresistentnosti. Patologicheskaya fiziologiya i 
eksperimentalnaya terapiya. 2010;1:40-47.

8. Alderete TL, Byrd-Williams CE, Toledo-Corral CM et al. Relationships between IGF-1 and IGFBP-1 and adiposity in obese African-American and Latino adolescents. Obesity (Silver Spring). 2011;19(5):933-938. Available from: https://doi.org/10.1038/ oby. 2010.211

9. Alzamil H. Elevated Serum TNF- \pm Is Related to Obesity in Type 2 Diabetes Mellitus and Is Associated with Glycemic Control and Insulin Resistance. J Obes. 2020;5076858. Available from: https:/ /doi.org/10.1155/2020/5076858

10. Arcidiacono B, Iiritano S, Nocera A et al. Insulin resistance and cancer risk: an overview of the pathogenetic mechanisms. Exp Diabetes Res. 2012;2012:789174. Available from: https://doi.org/ 10.1155/2012/789174

11. Bardou M, Barkun AN, Martel M. Obesity and colorectal cancer. Gut. 2013;62(6):933-947. Available from: http://dx.doi.org/ 10.1136/gutjnl-2013-304701

12. Beg MS, Dwivedi AK, Ahmad SA et al. Impact of Diabetes Mellitus on the Outcome of Pancreatic Cancer. PLoS One. 2014;9(5):e98511. Available from: https://doi.org/10.1371/ journal.pone.0098511

13. Federici M, Porzio O, Lauro D et al. Increased abundance of insulin/insulin-like growth factor-I hybrid receptors in skeletal muscle of obese subjects is correlated with in vivo insulin sensitivity. J Clin Endocrinol Metab.1998;83(8):2911-2915. Available from: https:// doi.org/10.1210/jcem.83.8.4935

14. Garcна-Jimйnez C, Gutiйrrez-Salmeryn M, Chocarro-Calvo A et al. From obesity to diabetes and cancer: epidemiological links and role of therapies. Br J Cancer. 2016;114(7):716-722. Available from: https://doi.org/10.1038/bjc.2016.37

15. Giovannucci E, Harlan DM, Archer MC et al. Diabetes and cancer: a consensus report. Diabetes Care. 2010;33(7):1674-1685. Available from: https://doi.org/10.2337/dc10-0666

16. GnaciDska M, MaBgorzewicz S, Guzek M et al. Adipose tissue activity in relation to overweight or obesity. Endokrynol Pol. 2010;61(2):160-168.

17. Hare $\mathrm{SH}$, Harvey AJ. mTOR function and therapeutic targeting in breast cancer. Am J Cancer Res. 2017;7(3):383-404.

18. Holmes AG, Mesa JL, Neill BA et al. Prolonged interleukin6 administration enhances glucose tolerance and increases skeletal muscle PPARa and UCP2 expressions in rats. J Endocrinol. 2008;198:367-374. Available from: https://doi.org/10.1677/JOE-080113

19. Huang X, Liu G, Guo J et al. The PI3K/AKT pathway in obesity and type 2 diabetes. Int J Biol Sci. 2018;14(11):1483-1496. Available from: https://doi.org/10.7150/ijbs.27173.

20. Jiang N, Dai Q, Su X, Fu J, Feng X, Peng J. Role of PI3K/ AKT pathway in cancer: the framework of malignant behavior. Mol Biol Rep. 2020;47(6):4587-4629. Available from: https://doi.org/ $10.1007 / \mathrm{s} 11033-020-05435-1$
21. Kim HR. Obesity-Related Colorectal Cancer: The Role of Leptin. Ann Coloproctol. 2015;31(6):209-210. Available from: https:/ /doi.org/10.3393/ac.2015.31.6.209

22. Liao KF, Lai SW, Li CI et al. Diabetes mellitus correlates with increased risk of pancreatic cancer: A population based cohort study in Taiwan. JGHF. 2012;27(4):709-713. Available from: https://doi.org/ 10.1111/j.1440-1746.2011.06938.

23. Nieto-Vazquez I, Fernбndez-Veledo S, de Alvaro C et al. Dual role of interleukin-6 in regulating insulin sensitivity in murine skeletal muscle. Diabetes. 2008;57(12):3211-3221. Available from: https:// doi.org/10.2337/db07-1062

24. Oberaigner W, Ebenbichler C, Oberaigner $\mathrm{K}$ et al. Increased cancer incidence risk in type 2 diabetes mellitus: results from a cohort study in Tyrol/Austria. BMC Public Health. 2014;10(14):1058. Available from: https://doi.org/10.1186/1471-2458-14-1058

25. Rajpathak SN, Gunter MJ, Wylie-Rosett J et al. The role of insulin-like growth factor-I and its binding proteins in glucose homeostasis and type 2 diabetes. Diabetes Metab Res Rev. 2009;25(1):3-12. Available from: https://oi.org/10.1002/dmrr.919

26. Ranjit S, Boutet E, Gandhi P et al. Regulation of fat specific protein 27 by isoproterenol and TNF- \pm to control lipolysis in murine adipocytes. J Lipid Res. 2011;52(2):221-36. Available from: https:// doi.org/10.1194/jlr.M008771

27. Shaw E, Farris M, McNeil J et al. Obesity and Endometrial Cancer. Recent Results Cancer Res. 2016;208:107-136. Available from: https://doi.org/10.1007/978-3-319-42542-9_7

28. Shikata K, Ninomiya T, Kiyohara $\bar{Y}$. Diabetes mellitus and cancer risk: Review of the epidemiological evidence. Cancer Sci. 2013;104(1):9-14. Available from: https://doi.org/10.1111/cas.12043

29. Tian W, Teng F, Zhao J et al. Estrogen and insulin synergistically promote type 1 endometrial cancer progression. Cancer Biol Ther. 2017;18(12):1000-1010. Available from: https://doi.org/ 10.1080/15384047.2017.1394547

30. Vatseba TS. Influence of pathogenetic factors of type 2 diabetes on activation of $\mathrm{PI} 3 \mathrm{~K} / \mathrm{AkT} / \mathrm{mTOR}$ pathway and on the development of endometrial and breast cancer. Regulatory Mechanisms in Biosystems. 2019;3(10):295-299. Available from: https://doi.org/ 10.15421/021945

31. Vatseba TS. Cancer of the organs of the reproductive system in women with type 2 diabetes. Effects of antidiabetic therapy. Wiadomo[ci Lekarskie. 2020;73(5):967-971. Available from: https:// doi.org/10.36740/WLek202005124

32. Xu CX, Zhu HH, Zhu YM. Diabetes and cancer:Associations, mechanisms, and implications for medical practice. World J Diabetes. 2014;5(3):372-80. Available from: https://doi.org/10.4239/ wjd.v5.i3.372

Received: 12.10 .2020

Revised: 12.11 .2020

Accepted: 12.11 .2020 